\title{
Micro-ultrastructure Features of Liver in Chinese Taihe Black-bone Silky Fowl (Gallus gallus domesticus Brisson)
}

\author{
Características Ultraestructurales de Hígado en la Gallina Silky China \\ Taihe de Hueso Negro (Gallus gallus domesticus Brisson)
}

Zhang, Hui*; Ge, Tingting*; Gandahi, Jameel Ahmed"*; Peng, Shasha*; Zhong, Shengwei"; Zhou, Zuohong*

ZHANG, HUI; GE, TINGTING; GANDAHI, JAMEELAHMED ; PENG, SHASHA; ZHONG, SHENGWEI; ZHOU, ZUOHONG. Micro-ultrastructure Features of Liver in Chinese Taihe Black-bone Silky Fowl (Gallus gallus domesticus Brisson). Int. J. Morphol., 32(3):1015-1021, 2014.

SUMMARY: In this work, the morphological features of liver in Chinese Taihe black-bone silky Fowl (BSF) were analyzed by light microscope and transmission electron microscopy. The results showed that two kinds of hepatocytes were present in Taihe BSF liver, i.e., the dark and the light hepatocyte. The dark hepatocyte was electron-dense and lager, with many organelles, mitochondria especially. The light hepatocytes were smaller than the dark. They had electron-lucent cytoplasm with a small number of organelles. Furthermore, there were lipolysosomes in the light hepatocyte. The numerous long and serried finger-like microvilli spread into bile canaliculus lumen. The glycogen granules intensely stained, spread in some hepatocytes. Numerous glycogen granules scattered in cytoplasm especially near bile canaliculi. However, lipid droplets were not observed in any hepatocytes. The natural apoptotic hepatocytes were observed in Taihe BSF liver. The hepatocytes which contain abundant uesicae-like endoplasmic reticulum closed the apoptotic hepatocytes and spread the process to approach the cell residual bodies. Besides, there was a macrophage with several phagosomes. In conclusion, the dark and the light hepatocyte were present in Chinese Taihe BSF liver. They were different from electron-dense and organelles. The hepatocytes of Taihe BSF could undergo natural apoptosis, regeneration and renew ability.

KEY WORDS: Chinese Taihe black-bone silky fowl; Liver; Ultrastructure

\section{INTRODUCTION}

The silky fowl (Gallus gallus domesticus Brisson) is noteworthy as a source of phenotypic variations not commonly seen in other domestic breeds of chicken, representing a few of the vast array of morphological differences present across various domesticated poultry species (Dorshort et al., 2010). There is a characteristic feature of the silky fowl when compared with the other common chickens (Muroya et al., 2000) is the presence of melanocytes in the skin, and the melanocytes can produce a lot of melanin in various organs including skin, muscles, periosteum, trachea, mesentery, digestive canals, ovary and testis (Tu et al., 2008), e.g., hyperpigmentation. Hyperpigmentation is an extremely rare condition in most of other homoeothermic vertebrates. This presents an opportunity to utilize the silky fowl as a biological model of hyperpigmentation that can be used to identify genes regulating potentially novel mechanisms of melanoctye migration, proliferation, and differentiation. Moreover, silky fowl can as a biological model of researching melanoma and cosmetics for white skin of human (Dorshorsr et al., 2010).

The silky fowl originate in China (Muroya et al. 2000; Faraco et al., 2001; Ortolani-Machado et al. 2007; Haw 2006). The Chinese Taihe Black-bone silky fowl (BSF; Gallus gallus domesticus Brisson) is a special species of rooster originating in the Taihe County, east of Wushan Mountain in the Jiangxi Province of China with hyperpigmentation, and has been raised for over 2000 years. The Taihe BSF is a special species with snow-white silky feather (Fig.1 A) but black skin (Fig.1 B, C), meat and bones (Fig.1 C). The orthodox Taihe BSF has ten apparent characteristics: crest, beards, blue comb, green earlobes, white silky feathers, black bones, black muscles, black skin,

\footnotetext{
* College of Animal Science and Technology, Jiangxi Agricultural University, Nanchang 330045, P.R.China

** Department of Animal Husbandry \& Veterinary Sciences, Sindh Agriculture University, Tandaojam 70060, Pakistan
} 


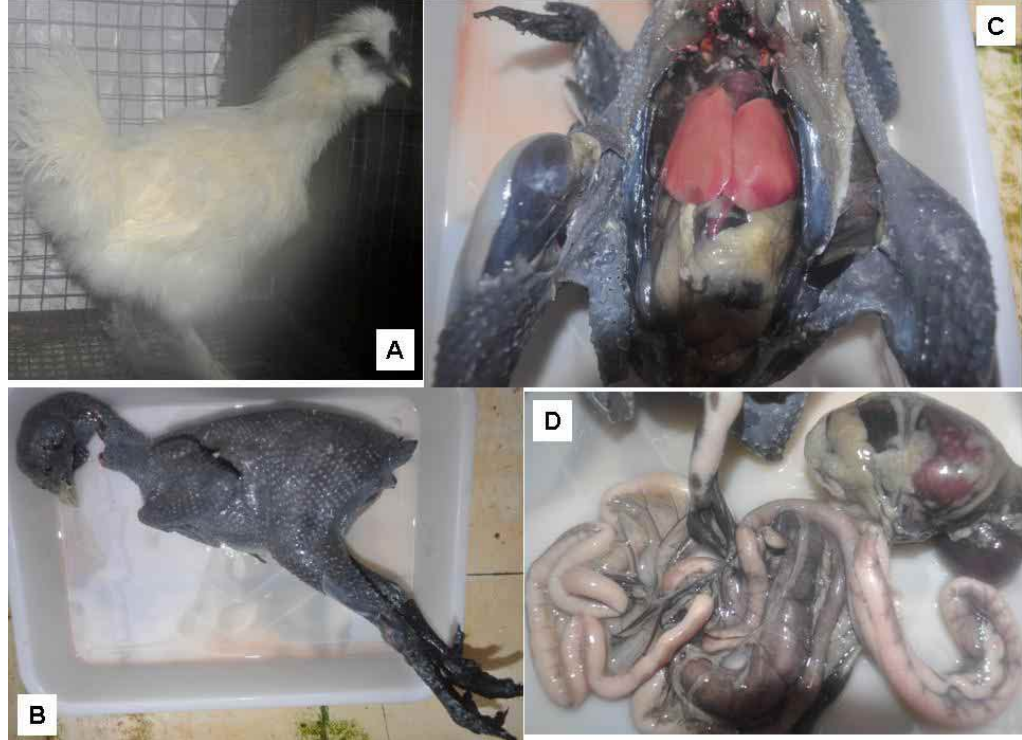

Fig. 1 physiognomy, skin and internal organs of Chinese Taihe BSF.

five toes and feathered shanks (Fig.1 A, B and C). Besides the skin, muscles and bone, abundant melanin in the connective tissue of internal organs (Fig.1 B, C, D). The Taihe BSF is generally accepted with nutritive value and drug action (Tian et al., 2007; Chen et al. 2008). They have a long history in Chinese culture and known as a marvel of traditional Chinese medicine for various ailments (Chen et al. 2008). To this day, they have been widely used in medicine, pharmacology, cosmetics, immune booster and a ward against emaciation and feebleness (Tian et al., 2007). Melanin can protect against mitochondrial superoxide generation and mtDNA damage (Swalwell et al., 2012). A study indicated Taihe BSF contains high levels of carnosine, which is a powerful antioxidant and is taken as a dietary supplement to strengthen muscles and to alleviate the effects of aging, autism and diabetes (Tian et al., 2007; Huang et al., 2002). The amino acid requirements for growing Chinese Taihe BSF had been investigated ( $\mathrm{Li}$ et al., 2003). However, the studies on the Chinese Taihe BSF are rare. The ultrastructure of internal organs in the Chinese Taihe BSF has not been illustrated up to now. The main goal of this work was to characterize structurally the liver in Taihe BSF, in an attempt to better understand the physiochemical property, morphological characterization, and biological activity of the liver in Taihe BSF, looking for new insights on the role of the liver in digestion and absorption, ever in hyperpigmentation. Furthermore, knowledge about the avian liver histology is therefore useful for comparison with the human liver. We expect the findings will provide more information in comparative histology.

\section{MATERIAL AND METHOD}

Taihe BSF. The post-hatching Taihe BSF were generously provided by the Taihe BSF Breeding Farm in Taihe county, Jiangxi province, China. The Taihe BSF were fed for 4 weeks with conventional chicken feed purchased from a commercial animal feed company.
Transmission electron microscopy. A standard procedure in ultra-thin sections was used. Briefly, after euthanized, the liver of the chicken was sampled. Samples were fixed in $2.5 \%$ glutaraldehyde and then washed three times in 0.1 M PBS. The sections were postfixed in $1 \% \mathrm{OsO}_{4}$, washed three times in 0.1 $M$ PBS, dehydrated in a series of concentration of ethanol, and then dehydrated two times in acetone, embedded in Spurr's resin at $37^{\circ} \mathrm{C}$ for $24 \mathrm{hr}$, and then at $60^{\circ} \mathrm{C} 48$ hr. After ultrasectioning with LKB-V type of ultra-thin slice machine (Bromma Company, Sweden), the ultra-thin sections were examined in a Hitachi H600 type transmission electron microscope (Japan).

\section{RESULTS}

Microstructure features of liver in Taihe BSF. The connective tissue was not well developed and the hepatic lobules were not apparent in Taihe BSF by light microscopy (Fig.2 A). The central veins were filled with many red blood cells with nuclei (fig. $2 \mathrm{~A}, \mathrm{C}$ ). The arrangement type of BSF liver plate was bilayer cell cord (Fig.2 B). The blood sinusoids with apparent endotheliocytes were well developed and contained red blood cells (Fig.2 B, C and D). The large and irregular Kuffer's cell was found occasionally (Fig.2 B). The double-nuclei and dividing hepatocytes were also observed in Taihe BSF liver (Fig.2 C). The transverse section bile canalicul were composed of 2-6 hepatocytes (Fig.2 D).

Ultrastructure features of liver in Taihe BSF. The hepatocyte of Taihe BSF generally had only one nucleus, which was round and relatively large, with a large nucleolus. Mitochondria were the most organelles in the hepatocytes and were densely packed in the electron-dense cytoplasmic matrix (Fig. $3 \mathrm{~A}$, B, C and D). They were ovoid and had various sizes with a double membrane. Mitochondrial cristae were arranged mostly in the transverse direction. Lysosomes were usually randomly distributed throughout the cytoplasm (Fig.3 D). It was unexpected that hardly any lipid droplets in liver of Taihe BSF. 


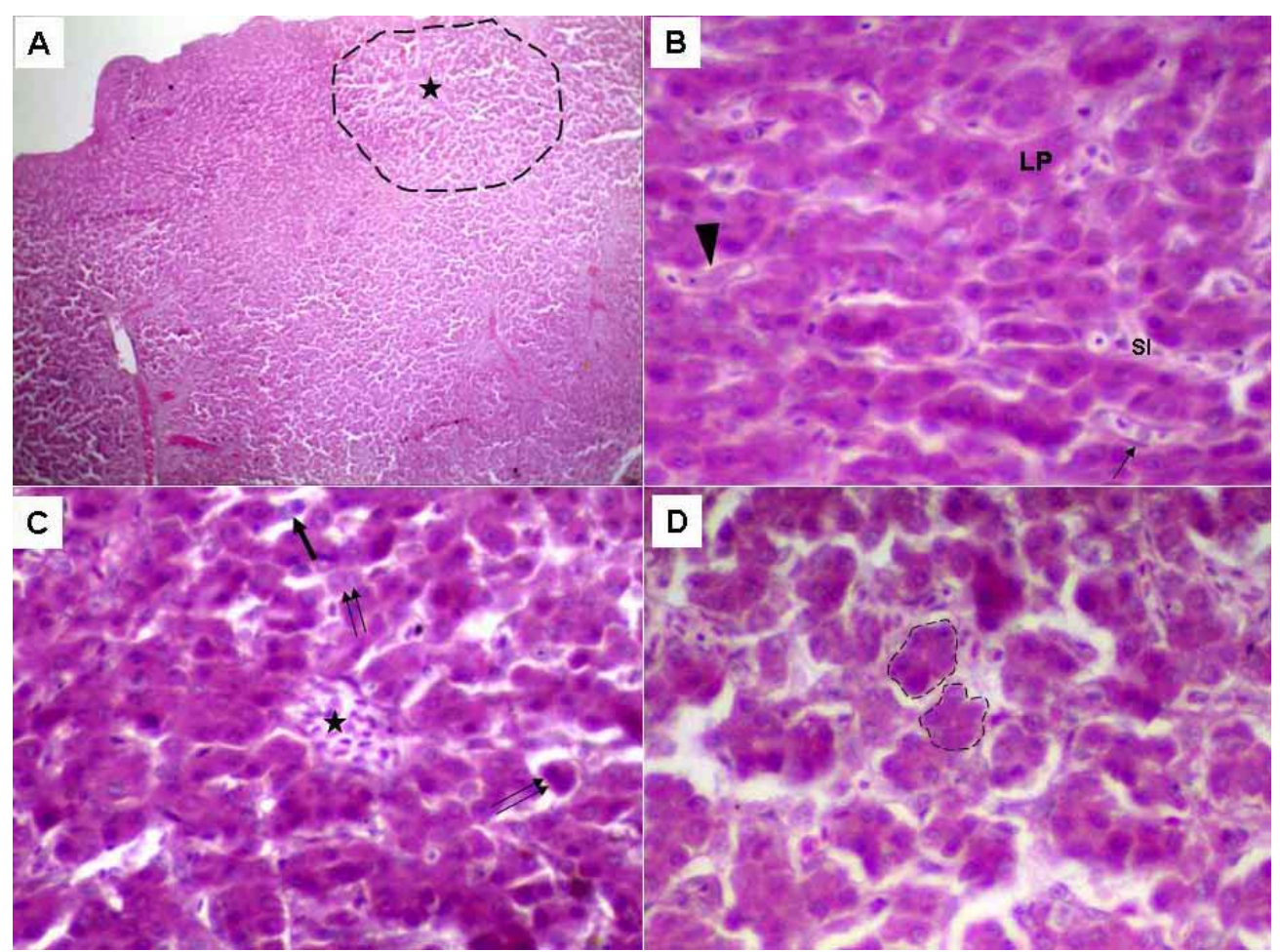

Fig. 2 Microstructure of liver in Taihe BSF (H\&E). Micrograph A (X100), others micrographs (X400). The dashed line denoted untypical hepatic lobule in micrograph A. The asterisk denoted central vein in micrograph A and C. The thin arrow denoted endothelial cells; the arrowhead denoted Kuffer's cell; the double arrows denoted double-nuclei hepatocytes; the thick arrow denoted dividing hepatocytes; the dashed line in micrograph D denoted transverse section bile canalicul. LP: liver plate; SI: Blood sinusoid.
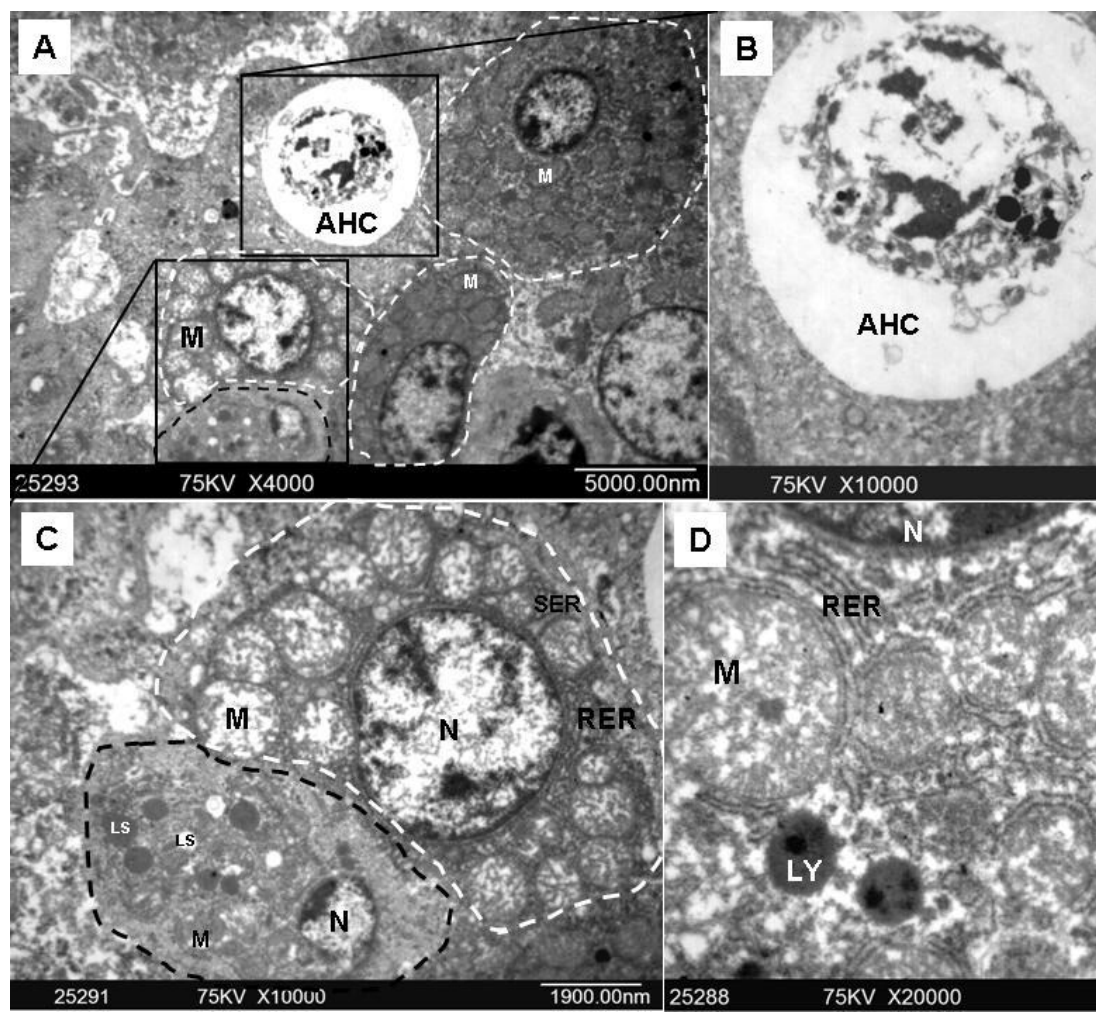

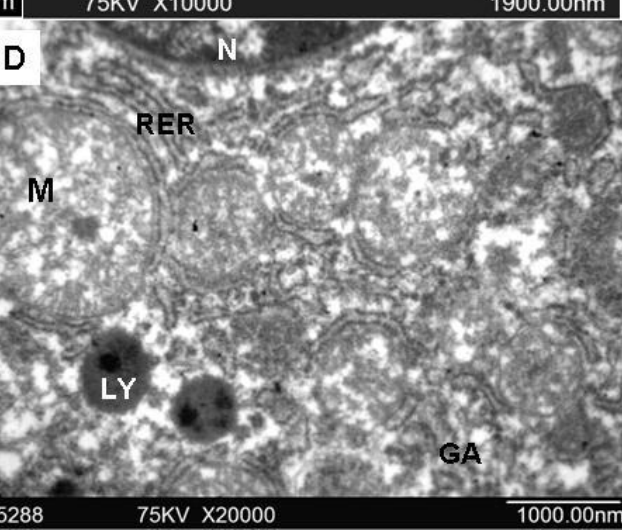

Fig. 3 The dark hepatocyte (white dashed line), the light hepatocyte (black dashed line), and the apoptotic hepatocytes (AHC) were in the Taihe BSF liver. The electron micrograph $B$ and $C$ were magnified from $\mathrm{A}$ to showed AHC, the dark and light hepatocytes respectively. The electron micrograph $\mathrm{D}$ denoted the organelles in the dark hepatocytes. M: mitochondrion; N: nucleus; RER: rough endoplasmic reticulum; LS: lipolysosome; AHC: apoptotic hepatocyte; LY: lysosome; GA: golgi apparatus. 
There were two kinds of hepatocytes in BSF liver apparently (Fig.3 A, C). One was the dark hepatocyte. The dark hepatocyte was electron-dense and lager with many organelles, including mitochondria, rough endoplasmic reticulum (RER) and Golgi apparatus. The mitochondria were considerable and round with various sizes, especially. Mostly mitochondria were surrounded by RER (Fig.3 D). The nucleus of dark hepatocyte was large and nucleoli were discrete. The round lysosomes were observed with electrondense in the dark hepatocyte (Fig.3 D). The other was the light hepatocyte (Fig. 3 C). These were smaller than the dark hepatocyte, and possessed electron-lucent cytoplasm with a small number of organelles, including a few relatively large mitochondria and a few short cisternae of RER. The nucleus of light hepatocyte was small. The nucleolus was secund and close to nuclear membrane. Furthermore, there were electron-dense spheres and electron-lucent bodies in the light hepatocyte (Fig. $3 \mathrm{C}$ ). The features of them were similar to lipolysosomes (LS). In addition, the apoptotic hepatocytes were observed in Taihe BSF liver (Fig.3 A, B).

Transverse sections of hepatic cell plates of the Taihe BSF liver consisted of hepatocytes cords arranged radially surrounding a central bile canaliculus (Fig.4 A, B). The biliary poles of the hepatocytes which formed the bile canaliculus were narrow and had numerous long and serried finger-like microvilli (Fig.4 B). Neighbouring hepatocytes formed adjacent occluding junctions close to bile canaliculus (Fig.4 B). The glycogen granules intensely stained spread in some hepatocytes. The glycogen was consistently observed as scattered areas of electron-lucent material in cytoplasm. Numerous glycogen granules scattered in cytoplasm where near to bile canaliculi in particular (Fig. 4
A). However, lipid droplets were not observed in any cells. The natural apoptotic hepatocytes with many different electron-dense and shape apoptotic bodies were observed in Taihe BSF liver (Fig.5 A, B, C and D). The dissociative ribosomes (RS) debris and constantly were observed around apoptotic hepatocytes (Fig.5 A). Abundant uesicae-like endoplasmic reticulum in hepatocytes that close apoptotic hepatocytes with process trending to cell residual bodies (Fig.5 B). Besides, there was macrophage with several phagosomes close to the apoptotic hepatocyte and spread the process to intake the apoptotic bodies (Fig.5 D).

\section{DISCUSSION}

The light and dark hepatocytes in Chinese Taihe BSF. The liver is the largest digestive gland and can synthesis different kinds of proteins and lipids. It is very important for digestion, absorption and metabolism in animals. Liver tissue is suitable for toxicological studies, especially (Roy et al., 2012; Alfazari et al., 2013; Wang et al., 2013). The light and dark cells are in many organs of others animals, however there is no agreement among many views about generation of these cells. There is controversy that whether the light and dark cell in liver. A study indicated that some teleosts and reptiles contain of dark and light cells (Leatherland and Sonstegard, 1988). However, it is different to in number of light and dark cells and organelles in all kinds of animals (Hou et al., 1999). Here, the light and dark hepatocytes were observed in Taihe BSF liver and the number and organelles of the dark hepatocytes were more than the light hepatocytes. Moreover, mostly mitochondria

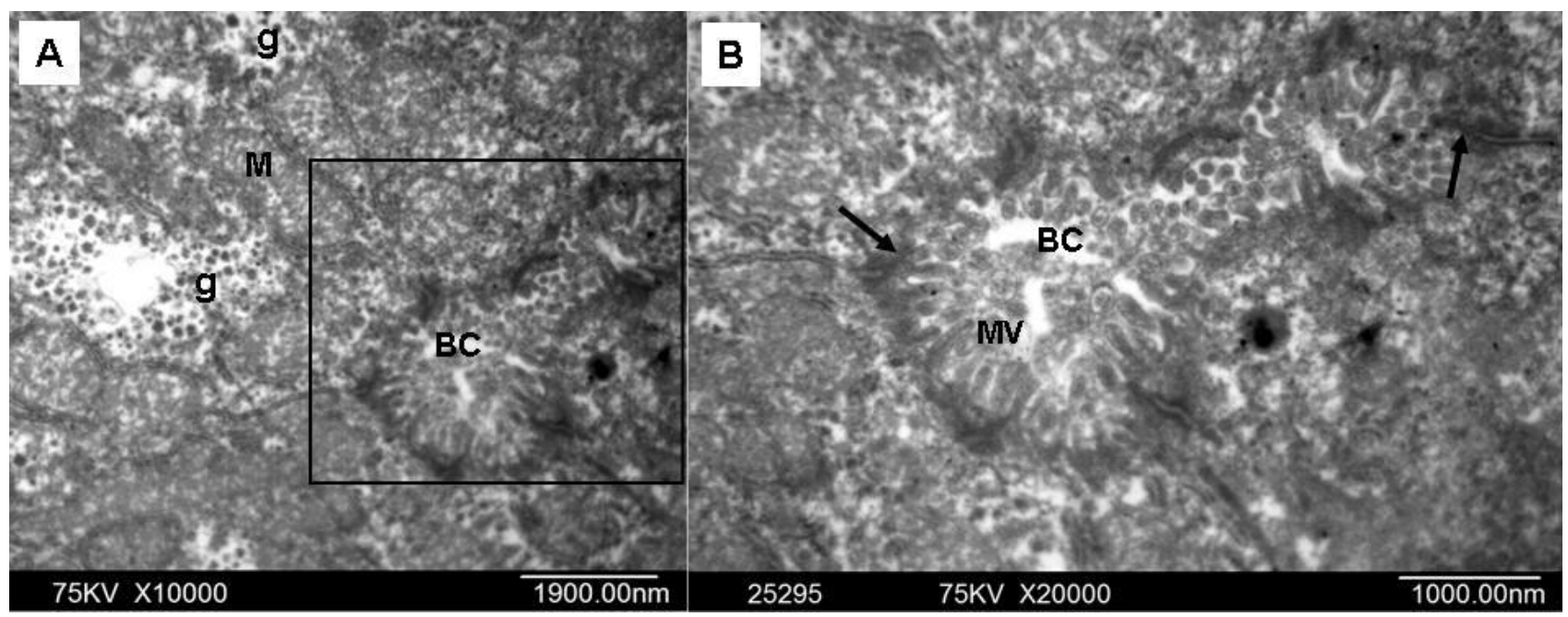

Fig. 4 Bile canaliculi were in Taihe BSF liver. Numerous mitochondria and glycogen granules scatter in cytoplasm that near to bile canaliculi. The electron micrograph B was magnified from A to show the bile canaliculi and adjacent occluding junctions (thick arrow). M: mitochondrion; G: glycogen granules; BC: bile canaliculi; MV: microvilli. 


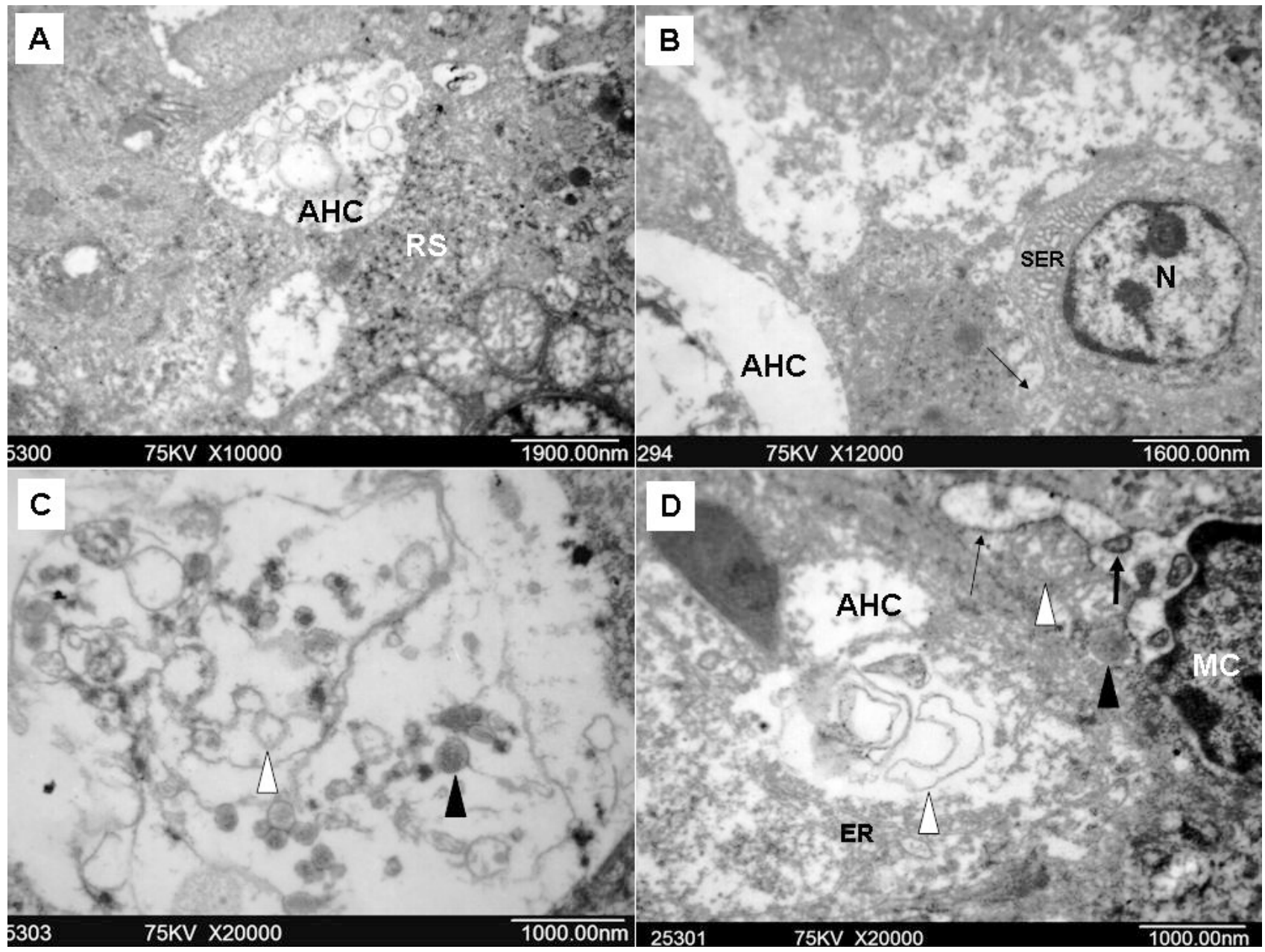

Fig. 5 The feartures of the natural apoptotic hepatocytes and nearby cells in liver of Taihe BSF. An apoptotic hepatocyte with several electron-dense (black arrowhead) and electron-lucent (white arrowhead) uesicaes and scattered dissociated ribosomes (electron micrograph $\mathrm{A}, \mathrm{C}$ and D). The hepatocytes contained abundant uesicae-like endoplasmic reticulum to close apoptotic hepatocytes with process (thin arrow) trending to cell residual bodies (electron micrograph B). The macrophage with several phagosomes (thick arrow) close to the apoptotic hepatocyte and spread the process (thin arrow) to intake the apoptotic bodies (electron micrograph D). AHC: apoptotic hepatocyte; MC: Macrophage; RS: ribosome; N: nucleus; SER: smooth endoplasmic reticulum; ER: endoplasmic reticulum.

were surrounded by RER in the dark hepatocytes, which indicated the dark cell was more active in functions. The organelles of the light hepatocytes were less than the dark hepatocytes, but the light hepatocytes had numerous different electron-dense vesicles. These vesicles were probably lipolysosomes. It was suggested that the light hepatocytes were also active which can store energy. Accordingly, the light and dark cells were different hepatocytes and had different roles in Taihe BSF liver. The dark cells were predominant cells to produce the proteins and lipids. The light cells were subcardinal cells and form lipolysosomes to provide energy.

Lipolysosomes. It was unexpected that hardly any lipid droplets were present in liver of Taihe BSF, but the lipolysosomes were observed in the light cell of Taihe BSF's liver. In general, accumulation of lipolysosomes was characteristic of chick hepatocytes during the embryonic period and shortly after hatching (Kanai et al., 1997). Lipolysosomes were mainly composed of esterified cholesterol and showed considerably high activity of lysosomal enzymes. When the supply of nutrients from the yolk sac was terminated, lipolysosomes immediately decreased in size and number. The cholesterol and fatty acids released were useful as an energy source and lipid metabolism in general, especially after hatching. Food intake induces the use of and accelerates the disappearance of lipolysosomes. Instead of lipolysosomes, lipid droplets appear and increase in number and size with concomitant increases of triglyceride concentrations in the liver 
homogenates, suggesting that lipogenesis had begun in the chick hepatocyte (Kanai et al., 1997). Moreover, the lipolysosome fraction was clearly shown to be a function of intralysosomal lipolysis via acid lipase. This accumulation of esterified cholesterol within lipolysosomes might be attributed to an excessive uptake and conversion of plasma lipoproteins to lipolysosomes (Kanai et al., 1997). In the present study, the lipid droplets were absence in liver of Taihe BSF, but glycogen and lipolysosomes were existent to supply energy. It is possible that glycogen and lipolysosomes produce ATP are prompter than lipid droplets.

Natural apoptosis and scavenge of hepatocytes in Taihe BSF. Some natural apoptotic hepatocytes with typical apoptotic body were observed in liver of Taihe BSF, which indicates that natural apoptosi of hepatocytes were frequent. It is possible that cell apoptosis conduce to get rid of effete, pathological, idle hepatocytes.

The hepatocytes that close to apoptotic hepatocytes contained abundant uesicae-like endoplasmic reticulum. The ER were similar to those of Brown' report in Xenopus laevis (Brown, 1978). Brown considered that hepatocytes contain abundant uesicae-like endoplasmic reticulum is active. Furthermore, the hepatocytes with processes trend to the apoptotic hepatocyte residual bodies. It indicated that the uesicae-like endoplasmic reticulum hepatocytes could possess pinocytosis. Besides, there was macrophage with several phagosomes close to the apoptotic hepatocyte and spread the processes to uptake the apoptotic bodys. Obviously, the macrophage can phagocytize the foreigner, effete cell and apoptotic body. Both cells can scavenge apoptotic hepatocytes and promote the hepatocytes to renew in Taihe BSF liver. It suggested that hepatocytes of Taihe $\mathrm{BSF}$ possess regeneration and renewal ability, thereby to keep consummate roles.

\section{ACKNOWLEDGMENTS}

This work was supported by Natural Science Foundation of Jiangxi Province (20122BAB214021), Natural Science Foundation of Department of Education of Jiangxi Province (GJJ13262).

ZHANG, HUI; GE, TINGTING; GANDAHI, JAMEEL AHMED ; PENG, SHASHA; ZHONG, SHENGWEI; ZHOU,

ZUOHONG.. Características ultraestructurales de Hígado en la Gallina Silky China Taihe de Hueso Negro (Gallus Gallus Domesticus Brisson). Int. J. Morphol., 32(3):1015-1021, 2014.

RESUMEN: Fueron analizadas las características morfológicas ultraestructurales de hígado en la gallina sedosa china de hueso negro por microscopía óptica y microscopía electrónica de transmisión. Los resultados mostraron que se encontraron hepatocitos claros y oscuros en el hígado de la gallina china Taihe. El hepatocito oscuro era denso y de mayor tamaño. Tenía numerosos organelos, especialmente mitocondrias. Los hepatocitos claros eran más pequeños que los oscuros. El citoplasma presentó un pequeño número de organelos. Además, había lipolisosomas en los hepatocitos claros. Numerosas microvellosidades se extendían hacia los canalículos biliares. En algunos hepatocitos se observó una tinción marcada en los gránulos de glucógeno. Sin embargo, no se observaron gotas de lípidos en los hepatocitos. Se observaron los hepatocitos apoptóticos naturales en el hígado de la gallina Silky Taihe. Aquellos hepatocitos que contenían abundante retículo endoplásmico, cerraban los hepatocitos apoptóticos y extendían el proceso de acercamiento a cuerpos residuales celulares. También hubo un macrófago con varios fagosomas. En conclusión, los hepatocitos claros y oscuros estaban presentes en el hígado de la gallina Taihe china. Estos diferían de electrones de alta densidad y organelos. Los hepatocitos de la gallina Taihe presentaron una apoptosis natural y capacidad de regeneración.

PALABRAS CLAVE: Gallina Silky China Taihe de Hueso Negro; Higado; Ultraestructural.

\section{REFERENCES}

Alfazari, A.S.; Al-Dabbagh, B.; Almarzooqi, S.; Albawardi, A. \& Souid, A.K. A preparation of murine liver fragments for in vitro studies: liver preparation for toxicological studies. BMC Res. Notes, 6:70, 2013.

Brown, D. Fenestrae in the rough endoplasmic reticulum of Xenopus laevis hepatocytes. Anat. Rec., 191(1):103-10, 1978.
Chen, S.R.; Jiang, B.; Zheng, J.X.; Xu, G.Y.; Li, J.Y. \& Yang, N. Isolation and characterization of natural melanin derived from silky fowl (Gallus gallus domesticus Brisson). Food Chemistry, 111(3):745-9, 2008.

Dorshorst, B.; Okimoto, R. \& Ashwell, C. Genomic regions associated with dermal hyperpigmentation, polydactyly and other morphological traits in the Silkie chicken. J. Hered., 101(3):339-50, 2010. 
Faraco, C.D.; Vaz, S.A.; Pastor, M.V. \& Erickson, C.A. Hyperpigmentation in the Silkie fowl correlates with abnormal migration of fate-restricted melanoblasts and loss of environmental barrier molecules. Dev. Dyn., 220(3): 212-25, 2001.

Muroya, S.; Tanabe, R.; Nakajima, I. \& Chikuni, K. Molecular characteristics and site specific distribution of the pigment of the silky fowl. J. Vet. Me. Sci., 62(4):391-5, 2000.

Haw, S.G. Marco Polo's China: a Venetian in the realm of Khubilai Khan. Routledge studies in the early history of Asia 3. London (NY): Routledge, 2006.

Hung, Y.C.; Sava, V.M.; Makan, S.Y.; Chen, T.H.J.; Hong, M.Y. \& Huang, G.S. Antioxidant activity of melanins derived from tea: Comparison between different oxidative states. Food Chemistry. 78(2): 233-40, 2002.

Hou, Y.Y.; Wang, W.Q. \& Zhou, X.B. A histological morphometrical and ultrastructural study of the development of the fetus liver. Acta. Acad. Med. Qingdao. 35(2):86-8, 1999.

Kanai, M.; Soji, T. \& Herbert., D.C. Biogenesis and function of lipolysosomes in developing chick hepatocytes. Microsc. Res. Tech., 39(5):444-52, 1997.

Leatherland, J.F. \& Sonstegard, R.A. Ultrastructure of the liver of Lake Erie coho salmon from post-hatching until spawning. Cytobios., 54(218-219):195-208, 1988.

Li, G.; Qu, M.; Zhu, N. \& Yan, X. Determination of the Amino Acid Requirements and Optimum Dietary Amino Acid Pattern for Growing Chinese Taihe Silky Fowls in Early Stage. AsianAust. J. Anim. Sci., 16(12):1782-8, 2003.

Ortolani-machado, C.; Freitas, P.D.; Borges, M.E. \& Faraco, C. Special features of dermal melanocytes in white silky fowl embryos. Anat. Rec., 291(1):55-64, 2007.

Roy, B.; Giri, B.R.; Chetia, M. \& Swargiary, A. Ultrastructural and biochemical alterations in rats exposed to crude extract of Carex baccans and Potentilla fulgens. Microsc. Microanal., 18(5):1067-76, 2012.

Swalwell, H.; Latimer, J.; Haywood, R. M. \& Birch-Machin, M.A. Investigating the role of melanin in UVA/UVB- and hydrogen peroxide-induced cellular and mitochondrial ROS production and mitochondrial DNA damage in human melanoma cells. Free Radic. Biol. Med., 52(3):626-34, 2012.

Tu, Y.G., Xie, M.Y.; Sun, Y.Z. \& Tian, Y.G.. Structural characterization of melanin from Black-bone silky fowl (Gallus gallus domesticus Brisson). Pigment Cell Melanoma Res., 22:134-6, 2008.

Tian, Y.G.; Xie, M.Y.; Wang, W.Y.; Wu, H.J.; Fu, Z.H. \& Lin, L.. Determination of carnosine in Black-Bone Silky Fowl (Gallus gallus domesticus Brisson) and common chicken by HPLC. Eur. Food Res. Technol., 226:311-4, 2007.

Wang, M.; Wang, Y.; Zhang, L.; Wang, J.; Hong, H. \& Wang, D. Quantitative proteomic analysis reveals the mode-of-action for chronic mercury hepatotoxicity to marine medaka (Oryzias melastigma). Aquat. Toxicol., 130-131:123-31, 2013.

\section{Corresponding Author:}

Zhou, Zuohong,

College of Animal Science and Technology Jiangxi Agricultural University

Nanchang 330045

P.R.CHINA

E-mail: zuohongzh@163.com

Recibido : 24-11-2013

Aceptado : 15-05-2014 